\title{
THE ROLE OF DOWN-REGULATION OF ANTIOXIDANT ENZYME ACTIVITIES AND REACTIVE OXYGEN SPECIES CHECKED ACCUMULATION IN PLAYING AN ESSENTIAL ACT IN SOYBEAN SUSCEPTIBILITY TO Fusarium virguliforme INFECTION \\ Ketta, H. A. \\ Department of Agricultural Botany, Branch of Plant Pathology, Faculty of Agriculture, Kafrelsheikh University, Kafrelsheikh 33516, Egypt. \\ E-mail: kettahammad@gmail.com
}

\begin{abstract}
Biochemical and histochemical analysis of soybean [Glycine max (L.) Merr.] cv. Giza 111 plants naturally infected with Fusarium virguliforme were studied to clarify the susceptibility mechanisms under open field conditions during 2015 growing season. Levels of superoxide $\left(\mathrm{O}_{2}{ }^{--}\right)$and hydrogen peroxide $\left(\mathrm{H}_{2} \mathrm{O}_{2}\right)$ which are the major reactive oxygen species (ROS) forms were significantly increased and accumulated after 3 and 5 days from symptom appearance in infected soybean plants. Also, electrolyte leakage (EL) values which indicate to the membrane permeability were increased after 3 days from symptom appearance, while the activities of catalase (CAT), peroxidase (POX) and polyphenol oxidase (PPO) enzymes were decreased. In addition, concentrations of chlorophyll A and B were significantly decreased in infected soybean plants in comparison with the uninfected one. Down-regulation of antioxidant enzyme activities might be the key role of soybean susceptibility to sudden death syndrome (SDS) infection which caused by soil-borne pathogen $F$. virguliforme. Antioxidant enzyme activities in infected plants were not enough for ROS-scavenging and initiated the programmed cell death and led for sudden wilt of susceptible plants. Plants showed wide range of defense responses in reaction to initiated invasion by the pathogen, including the production and accumulation of ROS by the process called "oxidative burst" which is the rapid and earliest step to produce large amounts of ROS and use them as weapons in a defense response system. Reactive oxygen species work also as signals which are able to stimulate other plant defense mechanisms. Steps of reactive oxygen species production and scavenging are highly dynamic and consists of a complex signaling network. Giving more attention to antioxidant enzyme activities and reactive oxygen species levels is needed for plant breeders in order to create a resistant soybean cultivars and might be useful for discovering a new alternative disease control strategies in which safety and decrease the environmental pollutions.

Keywords: Sudden death syndrome; Fusarium virguliforme; Antioxidants; Electrolyte leakage; Reactive oxygen species
\end{abstract}

\section{INTRODUCTION}

Soybean [Glycine max (L.) Merr.] considered one of the essential food and industrial crops on global level and its oilseed is the leading oil in the world (Wilcox 2004). Soybean seeds containing about $30 \%$ of cholesterol free oil. Among the legume crops, soybean has the highest protein content (Abdel-Monaim et al. 2011). Sudden death syndrome (SDS) disease which 
caused by soil-borne root fungus $F$. virguliforme (Aoki et al. 2003) formerly Fusarium solani f. sp. glycines occurs frequently and cause serious damage to soybean crop in producing countries. The fungus infects soybean root systems causing characteristic foliar symptoms which are commonly appeared after the flowering or pod development stages as interveinal chlorosis, mottling and/or mosaic and developing rapidly to interveinal necrotic streaks on the upper leaves (Sanogo and Yang 2001; Scherm and Yang 1996, 1998 and 1999). In aggressive cases, this is followed by an intensive wilt which lead to sudden death of soybean plants. In addition, necrosis of secondary roots and root rot may be appeared on roots and stems. Through infested soils, the soybean roots and stems under the soil line are often covered by a bluish masses of fungal sporulation consist from macroconidia (Hirrel 1983; Rupe 1989; Roy 1997a). The fungus has been found in lower stems and roots, but not isolated from soybean leaves (Roy 1997b; Roy et al. 1989; Rupe 1989). Sudden death syndrome disease has been recorded as a repeated problem causing huge yield losses in several areas of soybean production (Hartman et al. 1995; Rupe and Hartman 1999). Soybean biochemical and histochemical responses to $F$. virguliforme infection were recorded by Lozovaya et al. (2004 and 2006). Plants can defend themselves against invasion of pathogens by developing abroad range of responsive strategies which in many cases are associating with the production and scavenging of ROS processes in plants (Hafez et al. 2012). Gechev et al. (2002); Halliwell and Gutteridge (1999); Hafez and ElBaghdady (2013) reported that, the rapid formation of ROS such as superoxide $\left(\mathrm{O}_{2}^{-{ }^{-}}\right)$and hydrogen peroxide $\left(\mathrm{H}_{2} \mathrm{O}_{2}\right)$ is considered to be one of the earliest plant steps toward recognition of pathogens invading plants and up-regulate antioxidant systems against biotic stresses. It is known that in all aerobic organisms, ROS are considered products of various metabolic pathways including electron transmission in chloroplasts and mitochondria, catabolism of lipids and photorespiration in glyoxisomes and peroxisomes as well as enzymatic oxygenase reactions. Torres et al. (2006) explained that, the quick production of ROS in the apoplast in response to pathogen invasion might propose to coordinate various defensive walls against the pathogens. Asada and Takahashi (1987) reported that, oxidative molecules are highly toxic and might lead to the cell collapse. The oxidative burst theory which explained by Lamb and Dixon (1997) established that the quick production or accumulation of ROS in the pathogen invasion site is directly harmful to the pathogen. For avoidance of reactive oxygen species damage, plants protecting themselves by an antioxidant complex which includes metabolites and enzymes (for example: superoxide dismutase and peroxidases) which often acts at the reactive oxygen species production site (Lebeda et al. 2001). Apel and Hirt (2004) interpreted that, some enzymes are working to convert the superoxide into hydrogen peroxide (superoxide dismutase) and also convert hydrogen peroxide into water and oxygen gas (catalase). Although, energy of metabolism process is focused on ROS removing by plant cell, ROS under optimal growth conditions are also generated by cell metabolism processes (Heath 2000). Antioxidant enzyme activities might be are not enough for ROS-scavenging or detoxifying and initiated the programmed cell 
death and led for sudden death of susceptible plants in comparison with resistant plants.

The major objective of this research was aimed to clarify the biochemical and histochemical investigations to study the susceptibility mechanisms of soybean plants naturally infected with $F$. virguliforme the sudden death syndrome fungus. The down-regulation of antioxidant enzyme activities, ROS levels, disease severity, electrolyte leakage, chlorophyll $A$ and $B$ concentrations were determined.

\section{MATERIALS AND METHODS}

\section{Plant materials:}

Research work was conducted under the open field conditions with soybean cv. Giza 111 during 2015 growing season at the farm of Sakha Agricultural Research Station, Legume Department, Kafrelsheikh, Egypt. Soybean plant samples with interveinal chlorosis, mottling, or mosaic and interveinal necrotic streak symptoms on the upper leaves and uninfected plants were collected from two different localities (L1 and L2) of the same cultivar. In order to the similarity of foliar symptoms between soybean brown stem rot (BSR) disease and sudden death syndrome disease, stems near the soil line of infected plants were longitudinally cut and observed for browning the internal pith. Also, roots of symptomatic plants were examined for root decay.

\section{Disease severity assessments:}

Disease severity was recorded at the soybean growing stage (4 months-old) using a visual disease symptoms (leaf interveinal chlorosis and necrotic streaks) based on the scale of Mueller et al. (2002), where the scale started from 1 (no symptoms) to 9 (sever symptoms). Fifty plants of each locality were scored visually for percentage of infected plants. Disease severity index (DSI) was calculated according to the formula of Grau et al. (1982) for each locality:

$$
\text { DSI }=\frac{\Sigma \text { disease ratings of each plant }}{\text { total No. of plants rated } \times 9} \times 100
$$

Fungal pathogen was isolated by taking a part of infected soybean plant stems near the soil line and sterilized it by sodium hypochlorite solution ( $3.5 \%)$ for 5 minutes. The surface sterilized parts cut into small pieces after washing by sterilized water and placed on potato dextrose agar (PDA) then the hyphal tip was obtained and grown into potato dextrose broth (PDB). Potato dextrose agar was prepared by adding $33 \mathrm{mg} / \mathrm{ml}$ streptomycin sulfate solution with $40 \mathrm{mg} / \mathrm{ml}$ neomycin and $39 \mathrm{~g}$ Difco PDA/liter) for transformation the fungal isolate from PDB. Petri dishes with fungal culture were incubated at room temperature for 7-20 days with fluorescent light (approximately $10 \mathrm{~h}$ ). Grown mycelia were investigated microscopically and then identified according to Leslie and Summerell (2006) system. Pathogenicity test was done by fungal artificial inoculation to soybean cv. Giza 111 under the greenhouse conditions by insertion the colonized toothpicks under the 
cotyledons after 15 days from the sowing. Inoculated soybean seedlings were sprayed with sterilized water and incubated in a greenhouse conditions $\left(25^{\circ} \mathrm{C}\right)$. Toothpicks without inoculum were pricked under the cotyledons of soybean plants which used as control.

\section{Biochemical assays of antioxidant enzymes:}

For the measurement of antioxidant enzymes activities, infected ( 3 days from symptoms appearance) and uninfected soybean plants 4 monthsold were used. Three milliliters of $50 \mathrm{mM}$ TRIS buffer $(\mathrm{pH} 7.8)$ with $1 \mathrm{mM}$ EDTA- $\mathrm{Na}_{2}$ and polyvinylpyrrolidone $(7.5 \%)$ were used for homogenization of $0.5 \mathrm{~g}$ detached soybean leaves from localities 1 and 2. Centrifugation was carried out on $12000 \mathrm{rpm}$ for $20 \mathrm{~min}$. at $4^{\circ} \mathrm{C}$ for all homogenates. Supernatant of each homogenate was replaced for measuring the total soluble enzyme activity using spectrophotometer (UV-160A, Shimadzu, Japan).

\section{Catalase activity}

According to the protocol of Aebi (1984), the catalase activity was measured by spectrophotometer. Breakdown of hydrogen peroxide enzymatically recorded by decreasing the absorption of ultraviolet at wave length $240 \mathrm{~nm}$ for $3 \mathrm{~min}$. Catalase enzyme activity was calculated by changing of absorbance per min. per $g$ fresh weight. Fifty microliters of supernatant from leaf extract were mixed with $100 \mu \mathrm{l}$ of hydrogen peroxide, 2 $\mathrm{ml}$ of $0.1 \mathrm{M}$ sodium phosphate buffer $(\mathrm{pH} 6.5)$ in a final volume $2.15 \mathrm{ml}$.

\section{Peroxidase activity}

According to the protocol of Hammerschmidt et al. (1982), the POX activity with presence of guaiacol and hydrogen peroxide was measured by changing the ultraviolet absorbance at $470 \mathrm{~nm}$ for $30 \mathrm{sec}$. every $3 \mathrm{~min}$. intervals. Fifty microliters of supernatant from leaf extract were mixed with 50 $\mu$ moles of sodium acetate buffer ( $\mathrm{pH} 5.6), 60 \mu$ moles of guaiacol and 8 $\mu$ moles of hydrogen peroxide in a final volume of $3 \mathrm{ml}$. Peroxidase enzyme activity was calculated by changing of absorbance per min. per gram fresh weight.

\section{Polyphenol oxidase activity}

According to methods of Coseteng and Lee (1978), the PPO activity was measured by changing the ultraviolet absorbance at $420 \mathrm{~nm}$. Mixture of $0.1 \mathrm{M}$ phosphate buffer ( $\mathrm{pH} 6.0$ ), $20 \mathrm{mM}$ of catechol solution and $0.05 \mathrm{ml}$ of the enzyme solution was adjusted to final volume of $2.95 \mathrm{ml}$. PPO enzyme activity was calculated by changing of absorbance per min. per gram fresh weight.

\section{Histochemical analysis of reactive oxygen species:}

Soybean leaves of infected and uninfected plants were cut into small discs and collected to detect the superoxide $\left(\mathrm{O}_{2}{ }^{--}\right)$and hydrogen peroxide $\left(\mathrm{H}_{2} \mathrm{O}_{2}\right)$ production in leaf tissues. For detecting the superoxide production, leaf tissues were vacuum infiltrated according to Hagborg (1970) protocol by nitro blue tetrazolium (NBT) a classic photometric assay for detection the superoxide in leaf tissues. According to Ádám et al. (1989) the purple discoloration of leaf tissues was visualized after adding $10 \mathrm{mM}$ potassium phosphate buffer $(\mathrm{pH} 7.8)$ in presence of $0.1 \mathrm{w} / \mathrm{v} \%$ NBT (Sigma Aldrich, Germany). Treated leaf samples with NBT were replaced from the above solution and incubated for $20 \mathrm{~min}$. under daylight, then clearance of leaf 
samples was done in $0.15 \%$ trichloroacetic acid (wt/vol) in presence of ethanol : chloroform by ratio $4: 1$. Samples left at room temperature for $48 \mathrm{~h}$ and the clearing solution was replaced once during that period (Hückelhoven et al. 1999). After incubation period in clearing solution, leaf discs were immersed in glycerol (50\%) for next visualization. Quantification of leaves discoloration was done using nicked eyes or by digital imaging system (Chemilmager 4000, Alpha Innotech Crop., San Leandro, USA). For detecting the hydrogen peroxide production, leaf tissues were vacuum infiltrated with $0.1 \%$ 3-3'-diaminobenzidine (DAB) a (classic photometric assay for detection the hydrogen peroxide in leaf tissues in presence of 10 $\mathrm{mM}$ Tris buffer ( $\mathrm{pH}$ 7.8). Samples were transferred from the solution and incubated under daylight for two hours. Finally, leaves were cleared as described above and the intensity of brown color was estimated according to Hückelhoven et al. (1999).

\section{Electrolyte leakage assay:}

Freshly soybean leaves were cut into small discs (approx. $1 \mathrm{~cm}^{2}$ ) of infected and uninfected plants. Leaf discs were washed 3 times by deionized water (2-3 $\mathrm{min}$.), then replaced to flasks contain $25 \mathrm{ml}$ deionized water (Milli$\mathrm{Q}$ 50, Millipore, Bedford Mass., USA). After $20 \mathrm{~h}$ of shaking at room temperature, the electrolyte leakage (EL) was measured. Electrical conductimeter (Acromet AR20, Fisher Scientific, Chicago, IL) was used to record the initial conductivity for each sample vial. For inducing the cell tissues break, flasks contain samples were incubated at $80^{\circ} \mathrm{C}$ for $1 \mathrm{~h}$ in water bath (Fisher Isotemp, Indiana, PA), then the flasks were replaced for shaking (Innova 2100 platform shaker) for $20 \mathrm{~h}$ at $2^{\circ} \mathrm{C}$. Subsequently the final conductivity was recorded for each sample vial. Electrolyte leakage percentage was calculated for each disc according to formula of Szalai et al. (1996):

$$
\mathbf{E L}=\frac{\mathrm{EC} 1}{\mathrm{EC} 2} \times 100
$$

EC1: initial conductivity; EC2: final conductivity.

\section{Concentration of chlorophyll A and B:}

Chlorophyll (Chl.) concentration as $\mathrm{mg} / \mathrm{g}$ fresh weight of one gram fresh infected and uninfected soybean leaves was extracted within $5 \mathrm{ml} \mathrm{N}, \mathrm{N}$ dimethyl-formamid for overnight at $5^{\circ} \mathrm{C}$, then estimated $\mathrm{Chl}$. $\mathrm{A}$ and $\mathrm{B}$ spectrophotometry at 663 and $647 \mathrm{~nm}$ as explained by Moran and Porath (1982). The concentrations were calculated by the following equations: Chl. A $=12.76 A_{663}-2.79 A_{647}\left(\mathrm{mg} / \mathrm{g}\right.$ fresh weight), Chl. $B=20.76 A_{647}-4.62 A_{663}$ (mg/g fresh weight).

Statistical analysis:

Obtained data represent the mean \pm SD. For determination whether significant difference $(P<0.05)$ existed between mean values, Student's t-test was used (O'Mahony 1986). 


\title{
RESULTS AND DISCUSSION
}

\author{
Effect of $\boldsymbol{F}$. virguliforme infection on disease symptoms and disease \\ severity of soybean: \\ Typical known symptoms caused by F. virguliforme on soybean plants
} were observed during reproductive stages, but not frequently at vegetative stages. Bluish spore masses (Fig. $1 \mathrm{~A}$ ) which are the first signs of sudden death syndrome disease were occurred on stems near the soil line (infection site). Our obtained symptoms were typically similar to those symptoms of SDS which reported by Hirrel (1983); Rupe (1989); and Roy (1997a).
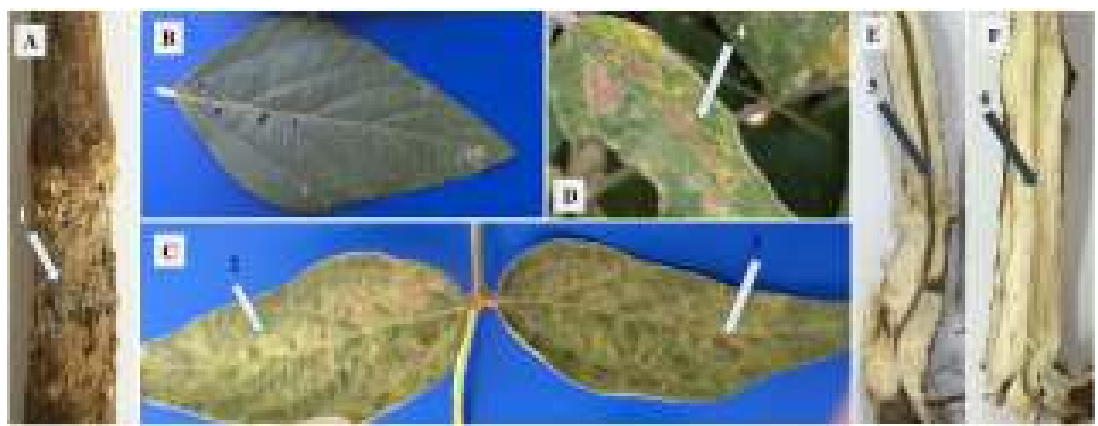

Figure 1. Disease symptoms of $F$. virguliforme on soybean cv. Giza 111 (4 months-old), A: classical stem symptoms of sudden death syndrome SDS disease under the soil line; 1- bluish spore masses; B: leaf of control plant; C: early foliar symptoms; 2interveinal chlorosis and 3- necrosis; D: disease progression; 4- interveinal necrotic streaks; E: pith symptoms of BSR; 5pith with brown color; F: classical SDS pith symptoms; 6- pith with white color.

More commonly "observable" symptoms with interveinal chlorosis and necrosis along the soybean leaves blade (Fig. $1 \mathrm{C}$ ) were evaluated in comparison with the uninfected leaves (Fig. $1 \mathrm{~B}$ ). As disease progresses further, the yellowing between the veins became brown (necrotic streaks) as the plants died (Fig. $1 \mathrm{D}$ ). However, the main damage to soybean plants was related to the foliar symptoms which are induced by the fungus infection or production of its toxins (might be moved systemically over the whole plant) under suitable wet and warm conditions ( $\mathrm{Li}$ et al. 2000; Jin et al. 1996). Splitting stems of infected soybean plants with a sharp knife was achieved. The pith of soybean plants which diseased with SDS remained basically white, while in case of BSR disease, pith browning a symptom characteristic of only BSR occurs within the central pith region instead was found (Fig. $1 \mathrm{E}$ and F). Also, root decay of symptomatic plants infected with SDS was found, while with the BSR were not observed. Disease severity percentage in two localities of soybean naturally infected $(\mathrm{L} 1=80 \%$ and $\mathrm{L} 2=77 \%$ ) with $F$. virguliforme at the growing stage (4 months-old) was significantly increased in 
comparison with the uninfected plants (Fig. 2). These obtained results suggesting that the $F$. virguliforme population could increase during the season by increasing the root system colonization during the plant growth stages. Our obtained results can be supported by the results published by Díaz et al. (2013). The identification of $F$. virguliforme by microscopic observations (Fig. 3) was achieved and the morphological characters of monophialides, macroconidia, areal mycelia and Chlamydospores were typically similar with the published identification system of Leslie and Summerell (2006). Pathogenicity of the fungus was confirmed by artificial inoculation of soybean plants under the greenhouse conditions and typical symptoms to those of SDS which recorded in open field were obtained.

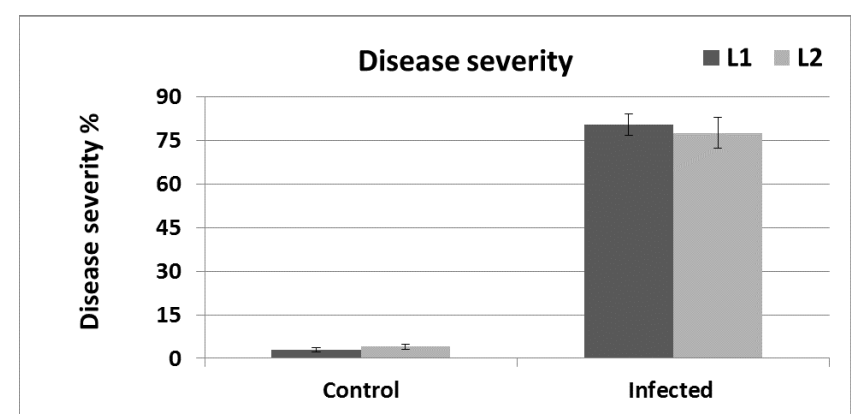

Figure 2. Disease severity percentage of SDS-susceptible soybean cultivar G111 (4 months-old) naturally infected with $F$. virguliforme in two localities (L1 and L2). Control: uninfected soybean; Infected: soybean infected with $F$. virguliforme.
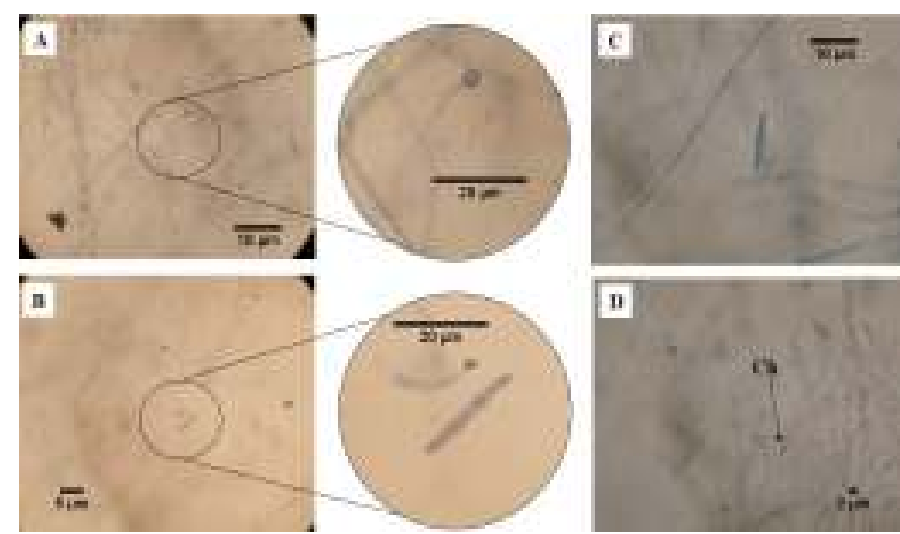

Figure 3. Microscopic observations of F. virguliforme: A- Monophialide; B- Macroconidia; C- Areal mycelia with macroconidium and DCh: Chlamydospore. Used scale bars: $A=10 \mu \mathrm{m}$; its magnification $=20 \mu \mathrm{m} ; B=5 \mu \mathrm{m}$; its magnification $=20 \mu \mathrm{m} ; C$ $=10 \mu \mathrm{m}$ and $\mathrm{D}=2 \mu \mathrm{m}$. 


\section{Effect of $F$. virguliforme infection on antioxidant enzymes activities in} soybean:

Antioxidant enzymes activities in susceptible soybean plants naturally infected with SDS fungus were undertaken. According to the obtained results, antioxidant enzyme activities of CAT, POX and PPO have been downregulated in infected soybean plants after 3 days from symptom appearance with SDS pathogen in comparison with the uninfected plants (Fig. 4). It is clearly known that the plants can defend themselves against pathogens early through initial responses playing an essential role in the stimulation of ROS detoxifying or scavenging enzymes. Foyer and Noctor (2005); Mittler et al. (2004); Van Breusegem and Dat (2006) reported that, antioxidant enzymes are working in two ways for keeping up ROS in steady state level. First way is working in normal cases without stresses to promote the plant growth development and signaling by hormones, while the second one is working for supplement responses toward biotic or even a biotic stressors. Equilibrium between ROS generating and scavenging is very important to protect plants against damage, but in case of pathogen attack the equilibrium often disturb and the sudden increase of ROS may happened causing serious damage to structure of plant cells. However, the sensitivity and specificity of plant cells to ROS are associated with the antioxidant level of a given cell at a given time. Torres et al. (2006) explained that, the accelerated production of ROS in the apoplast in response to pathogen invasion might propose to coordinate various defensive walls against the pathogens. The rapid increase of antioxidant enzymes activities may be revealed after inoculation with Phoma medicaginis to resistant lines of Medicago truncatula (Djebali et al. 2007) and is also happened with mungbean (Vigna radiata) when sprayed with elicitors obtained from Mcrophomina phaseolina (Vidhyasekaran et al. 2002). Scavenging of ROS or detoxification of its excess reported to be happened by antioxidative program which consists of enzymatic [catalase, peroxidase, polyphenol oxidase, superoxide dismutase, guaiacol peroxidase (GPX), ascorbate-glutathione (AsA-GSH), monodehydroascorbate reductase (MDHAR), ascorbate peroxidase (APX), glutathione reductase (GR) and dehydroascorbate reductase (DHAR)] and/or nonenzymic [tocopherols, ascorbate (AsA), glutathione (GSH), carotenoids and phenolic compounds] antioxidants (Noctor and Foyer 1998).

Previous researches established that the pathogens may defeated by the plant resistance through production of POX and PPO which participating in the defense system responding (Ray et al. 1998; Hafez et al. 2014; Abdelaal et al. 2014). The mechanisms of soybean susceptibility response toward infection with SDS seems to be correlated with the down-regulation and decrease of POX activity. Similarly, the sensitive response happened because late recognition of pathogen and the plant sudden wilt was parallel with decreasing of POX activity. The oxidation process of phenolic compounds to quinines by $\mathrm{POX}$ and $\mathrm{PPO}$ is very important against pathogens and act as antimicrobial activity. Accordingly, plants can prevent and inhibit the pathogen growth inside the cells by generating a toxic environment which may directly stopped the pathogen development and in the same time developed the cell death action. Family of peroxidases 
consists of complicated proteins which are universal in plant tissues causing cell wall relaxation and plant elongation during defense reaction by using $\mathrm{H}_{2} \mathrm{O}_{2}$ in oxidoreduction of different substrates (Almagro et al. 2009). There are a lot of reactions might be regulated by POX activity such as the balance in cell wall components between cleavage and cross-linking through $\mathrm{H}_{2} \mathrm{O}_{2}$ and ascorbate concentrations (Passardi et al. 2004). CAT activity was also decreased in soybean leaves of infected plants in the results obtained. This decrease in catalase activity may not provide its protection from oxidative damage caused by $\mathrm{H}_{2} \mathrm{O}_{2}$. Catalase enzyme is playing an essential role in plant defense reaction by dismutation $\mathrm{H}_{2} \mathrm{O}_{2}$ to oxygen and water. The obtained results are in agreement with El-Khallal (2007) who found that, antioxidant enzymes activities in leaves under $F$. oxysporum infection increased and were effective in scavenging mechanism to eliminate $\mathrm{H}_{2} \mathrm{O}_{2}$ and $\mathrm{O}_{2}{ }^{--}$which produced in leaves of resistant plants. Degrading enzymes of $\mathrm{H}_{2} \mathrm{O}_{2}$ (peroxisomes are the major sites of production during photorespiratory oxidation and oxidation of fatty acids) in plants existed through several types, however CAT enzyme is very important because of its fast turnover rate and dos not require any cellular reducing equivalents (Scandalios et al. 1997; Del Río et al. 2006; Corpas et al. 2008).

Therefore, from our obtained results we suggested that, the downregulation of antioxidants may be partially related with the soybean susceptibility to SDS fungus infection. Low obtained values of antioxidant enzymes activities in susceptible soybean plants may be due to the absence of resistance gene expression. Our theory could be supported with previous results of Polkowska-Kowalczyk and Maciejewska (2001) who found that the peroxidase enzyme activity did not change when Solanum (sensitive genotype) cell culture was treated by elicitors of Phytophthora infestans culture filtrate. 
Ketta, H. A.
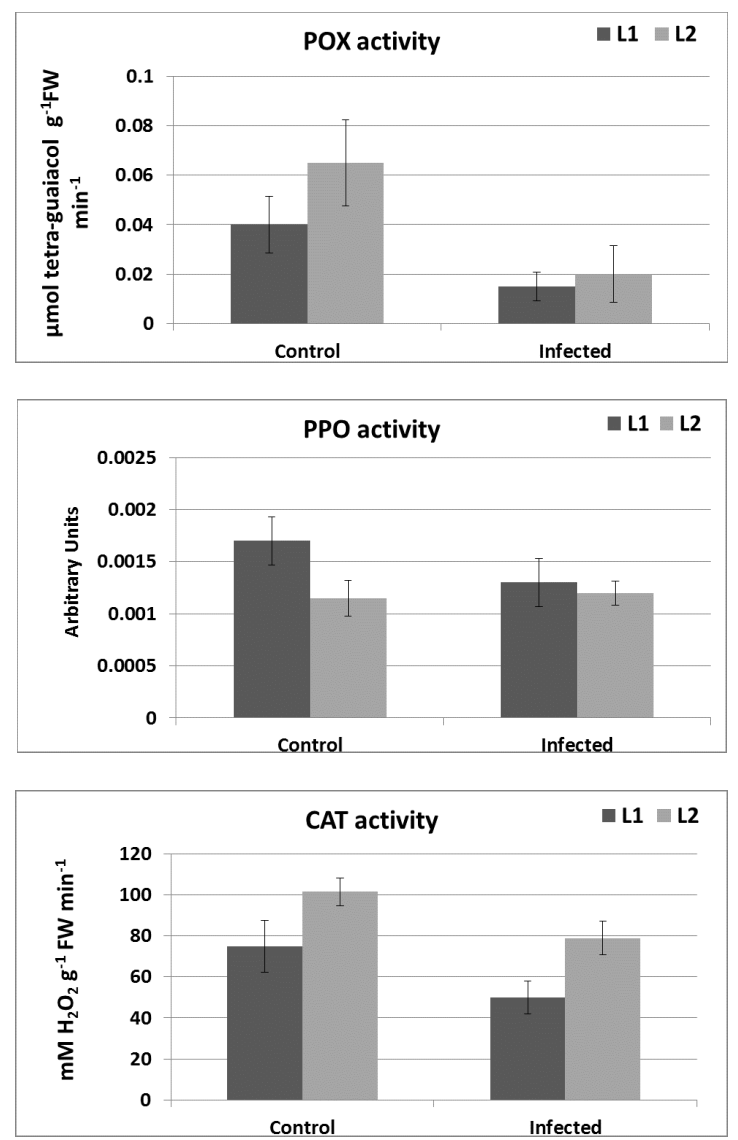

Figure 4. Antioxidant enzymes activities of peroxidase (POX), polyphenol oxidase (PPO) and catalase (CAT) respectively in susceptible soybean cultivar G111 infected naturally with $F$. virguliforme after 3 days from symptoms appearance in two localities (L1 and L2). Control: uninfected soybean; Infected: soybean infected with $F$. virguliforme.

Effect of $F$. virguliforme infection on levels of reactive oxygen species in soybean:

Brown discoloration of hydrogen peroxide $\left(\mathrm{H}_{2} \mathrm{O}_{2}\right)$ and purple discoloration of superoxide $\left(\mathrm{O}_{2}^{--}\right)$indicated to the intensity of ROS levels in the infected and uninfected soybean plant leaves which cleared from chlorophyll (Fig. 5). Levels of ROS mainly $\mathrm{H}_{2} \mathrm{O}_{2}$ and $\mathrm{O}_{2}{ }^{--}$significantly accumulated after 3 days from symptom appearance in infected soybean plant leaves in comparison with uninfected plants. Previous reports demonstrated that there is a distinct correlation between inhibition of plant pathogens in resistant plants and ROS generation, but the relationship between these two events (i.e. ROS accumulation for disease resistance) is 
not entirely clear (Király et al. 2103). Reactive oxygen species production in soybean plants by chloroplasts (energy transfer during photosynthesis process or during oxygen molecules reduction), mitochondria and peroxisomes, could inhibit its toxins or even kill pathogens early after infection. Several plant responses seems to be mediated by ROS when acting as signaling molecules in low concentrations, while causing damage to cell components when acting in high concentrations (Sharma et al. 2012). Moreover, in susceptible plants, pathogen growth is uninhibited and accordingly disease symptoms appeared possibly because there is no ROS accumulation after infection (Harrach et al. 2008; El-Zahaby et al. 1995). The heavy brown and purple discoloration intensity indicated to increased levels of $\mathrm{O}_{2}{ }^{\cdot-}$ and $\mathrm{H}_{2} \mathrm{O}_{2}$, respectively (Fig. 6 and 7). Color measurements on soybean leaves resulted by DAB or NBT staining indicated that, levels of ROS were significantly increased in infected plants in comparison with the uninfected one after 3 days from symptom appearance and still increased also after 5 days (Fig. 6 and 7). It has been reported that $\mathrm{O}_{2}{ }^{--}$is usually the first ROS to be generated in response to pathogen invasion. Hydrogen peroxide plays dual role for stimulation the cellular protective genes (healthy case) and localization death of infected cells (Martinez et al. 2000; Atia et al. 2005; Levine et al. 1994). Catalase and peroxidase enzymes are able to degrade the $\mathrm{H}_{2} \mathrm{O}_{2}$ which generated by superoxide dismutase enzyme.

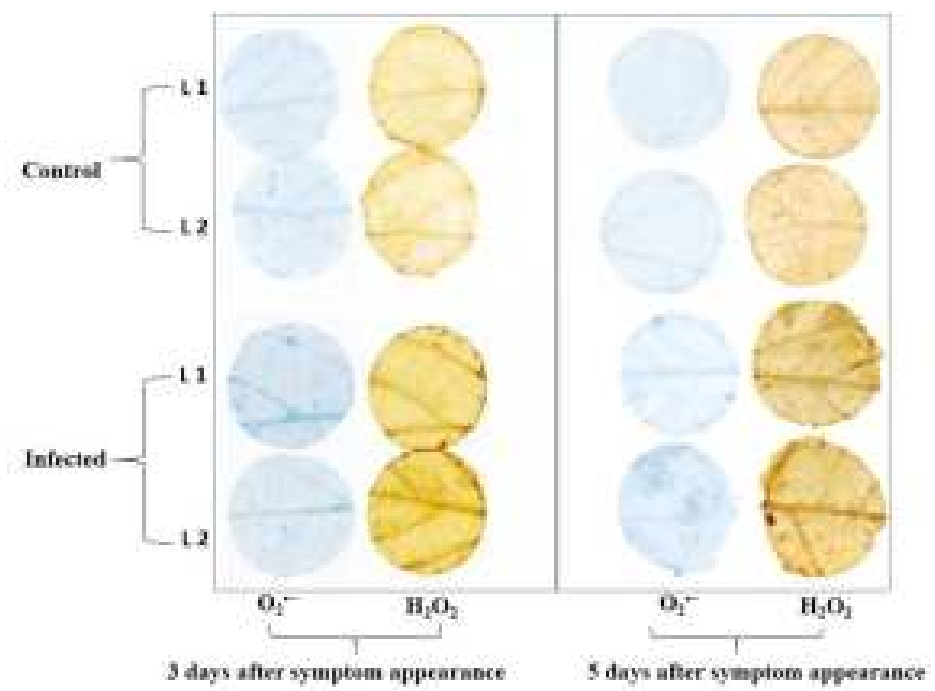

Figure 5. Reactive oxygen species accumulation: purple discoloration of superoxide $\left(\mathrm{O}_{2}{ }^{\circ-}\right)$ and brown discoloration of hydrogen peroxide $\left(\mathrm{H}_{2} \mathrm{O}_{2}\right)$ in infected and uninfected soybean plants after 3 and 5 days from symptom appearance with SDS disease under naturally infection in two localities (L1 and L2). Control: uninfected soybean; Infected: soybean infected with F. virguliforme. 
According to our obtained results of ROS levels mainly $\mathrm{H}_{2} \mathrm{O}_{2}$ and $\mathrm{O}_{2}{ }^{--}$ which were significantly accumulated after 3 days from symptom appearance in infected soybean plant leaves in comparison with uninfected plants and still increased till 5 days from symptom appearance. In our study, we suggest that the increasing of ROS levels over the time may be led to initiate the programmed cell death and the sudden death of susceptible soybean plants was happened. Recently, early accumulation of ROS after pathogen infection play essential dual role in host resistant and non-host resistant plant/pathogen combinations. The first role is killing or inhibiting the pathogen, while the second is stimulating the antioxidants activity in plants later (Hafez and El-Bagdady 2013; Hafez 2015). The dual role of early accumulation of ROS could be called "immunization of plants" (Hafez et al. 2012).
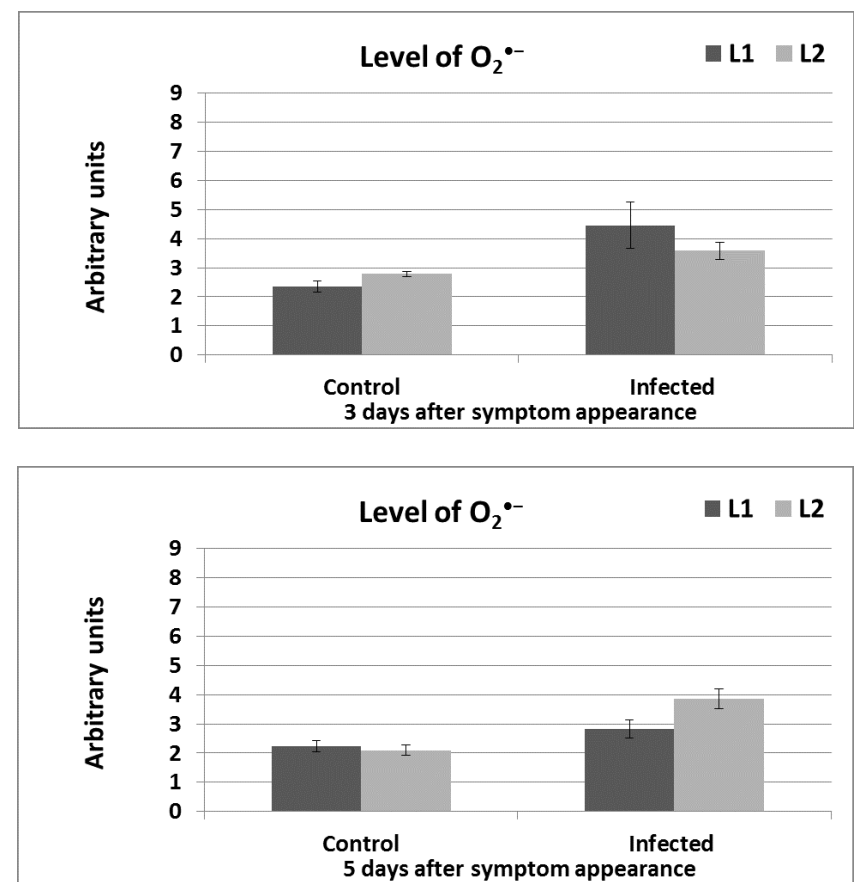

Figure 6. Levels of superoxide $\left(\mathrm{O}_{2}{ }^{--}\right)$in infected and uninfected soybean plants after 3 (upper diagram) and 5 (lower diagram) days from symptom appearance of SDS disease under natural infection in two localities (L1 and L2). Control: uninfected soybean; Infected: soybean infected with $F$. virguliforme. 

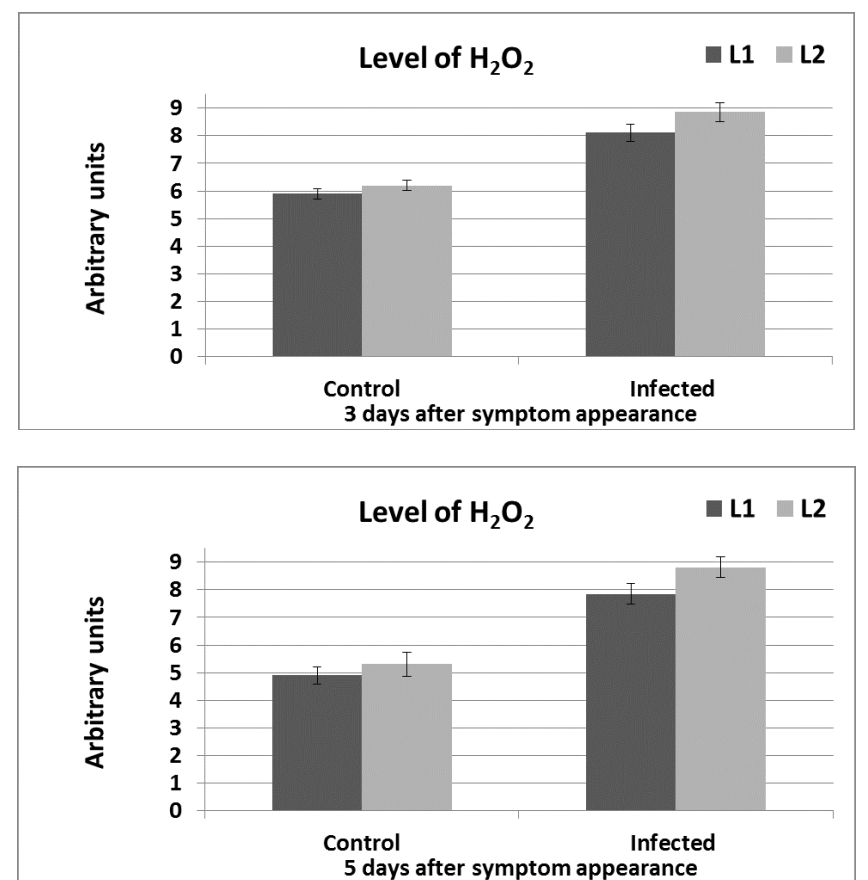

Figure 7. Levels of hydrogen peroxide $\left(\mathrm{H}_{2} \mathrm{O}_{2}\right)$ in infected and uninfected soybean plants after 3 (upper diagram) and 5 (lower diagram) days from symptom appearance of SDS disease under natural infection in two localities (L1 and L2). Control: uninfected soybean; Infected: soybean infected with $F$. virguliforme.

Effect of $F$. virguliforme infection on electrolyte leakage in soybean:

Soybean membrane damage was evaluated through electrolyte leakage (membrane permeability, integrity and cellular compartmentation indicator) under fungus infection. For measuring the cell membrane damage in response to biotic stresses, electrolyte leakage was used (Adam et al. 2000; Sriram et al. 2000) and also was used with biotic stresses (Pearce 2001; Zhou et al. 2005; Abbas 2012). Electrolyte leakage values were significantly increased in soybean plants naturally infected with $F$. virguliforme after 3 days from symptom appearance compared to the uninfected plants of the same cultivar (Fig. 8). Cellular membrane defect (increasing permeability and ion leakage) caused by pathogen attack is considered to be one of the most popular effects after infection and could be determined by electrolyte efflux. Plant reactive oxygen species are always generated by the unavoidable leakage of electrons onto $\mathrm{O}_{2}$ from the electron transport activities of byproduct of various metabolic pathways localized in different cellular compartments or chloroplasts, mitochondria, and plasma membranes (Del Río et al. 2006; Blokhina and Fagerstedt 2010; Heyno et al. 2011). 


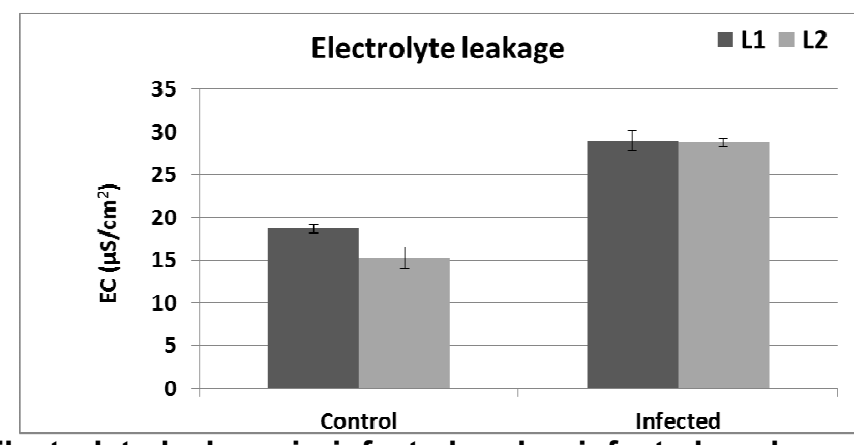

Figure 8. Electrolyte leakage in infected and uninfected soybean plants after 3 days from symptom appearance with sudden death syndrome SDS disease under natural infection in two localities (L1 and L2). Control: uninfected soybean; Infected: soybean infected with $F$. virguliforme.

In the present work, infection by $F$. virguliforme did increase the electrolyte leakage of susceptible soybean plants than with the uninfected plants. The SDS fungus depends on the soybean host cells for essential metabolic compounds, this could be the result of pathogen-host compatibility. These results supported by results obtained by Hafez et al. (2014) which chemical compounds and/or abiotic stresses could change the ability of plants to be resistant or susceptible through their changing in membrane permeability. Membrane damage following chilling has been evaluated by electrolyte leakage (Wright and Simon 1973; Simon 1974). Leakage points may result from the appearance of membrane domains presenting various configurations as a result of cold-induced changes in lipid phases (Leshem 1987), or from damage of membrane, particularly as regards lipids (Harwood 1997). Consequently, plant susceptibility could be induced using high temperature which effect the membrane permeability by increasing the electrolyte leakage values (Garraway et al. 1989). Also the ethylene affects membrane permeability (Goodman et al. 1986). This could be the way for understanding the relationship between uptakes the nutrients by pathogen and loss of host cells' components.

Our obtained results suggested that, infected soybean plants cannot protect their cell membranes and lost its components because of the pathogen attack, however the cell membranes of uninfected plants was not affected. Present results are in agreement with those obtained by Houimli et al. (2010).

Effect of $F$. virguliforme infection on chlorophyll $A$ and $B$ concentrations:

Chlorophyll A and B concentrations were decreased in infected soybean plants after 3 days from symptoms appearance compared to the uninfected plants (Fig. 9). It is common that plant photosynthesis process might be affected either biotic or abiotic stresses. Foliar damage by fungal infection is correlated with the photosynthesis and the arte of respiration 
(Scholes 1994). It seems that concentrations of chlorophyll A and B are highly correlated with the degrees of infection. The phenomenon of photosynthetic process inhibition by pathogens damaging leaf tissue has been already explained in literature of Giocoechea et al. (2001) and Robert et al. (2004). Similar results were obtained by Moriondo et al. (2005) and Lindenthal et al. (2005) in squash plants infected with downy mildew and wheat cultivars inoculated with stripe rust Puccinia striiformis. Photosynthetic steps could be related to the genes encoding chlorophyll $a / b$-binding proteins which appeared in response to pathogen invasion (Xin et al. 2012). In our results, chlorophyll $A$ and $B$ were decreased perhaps due to spreading the pathogen or its toxin within the infected soybean plants. This thought to destabilize the cell structural integrity, which reduces chlorophyll pigments in soybean infected with SDS disease and might be due to the decrease in the number and abnormal chloroplasts form in the mesophyll tissue. Decrease of chlorophyll concentrations could be correlated with the increase in disease severity.
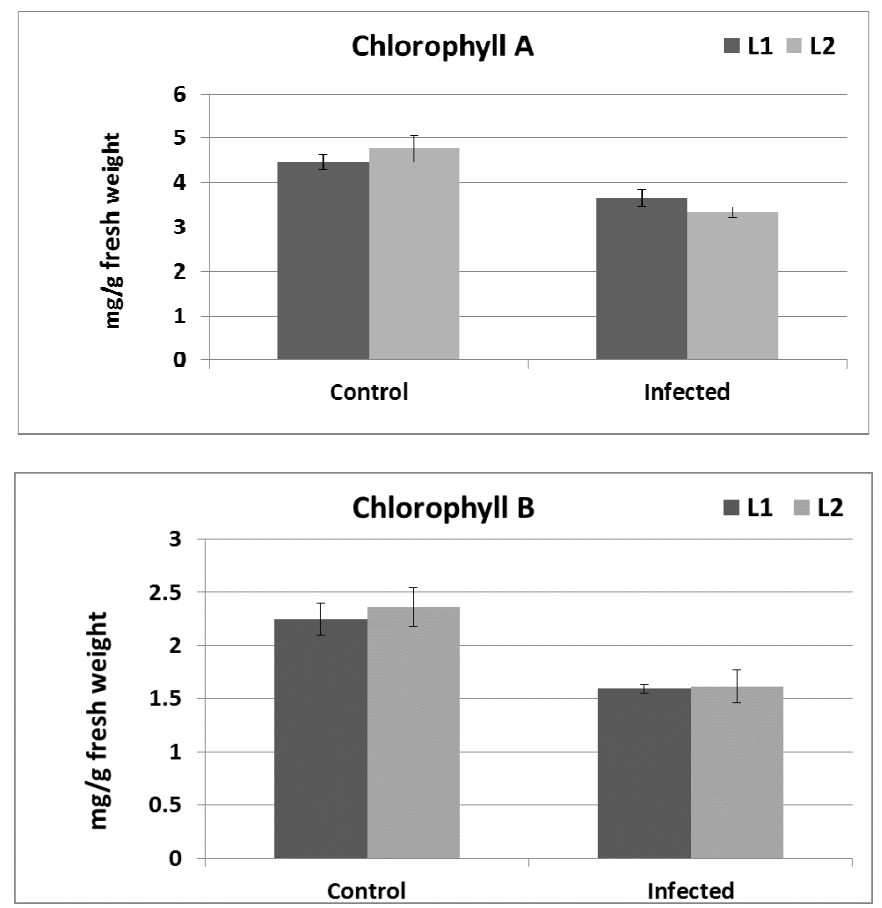

Figure 9. Chlorophyll A (upper diagram) and chlorophyll B (lower diagram) concentrations in infected and uninfected soybean cultivar after 3 days from symptom appearance with sudden death syndrome SDS fungus under natural infection in two localities (L1 and L2). Control: uninfected soybean; Infected: soybean infected with $F$. virguliforme. 
The obtained results represent one of the first studies focused on decreasing of antioxidant enzymes activity levels (down-regulation) of which the key role of soybean susceptibility to sudden death syndrome infection caused by soil-borne root pathogen $F$. virguliforme. From the viewpoint of biochemical and histochemical changes as well as changes in the activity of antioxidant enzymes in plants in response to the fungal infection. Results suggested that susceptibility of soybean plants to $F$. virguliforme infection is characterized by the decrease of antioxidant enzyme activities which is parallel to plant cell death. Disease severity percentage in two localities of soybean naturally infected with $F$. virguliforme at the growing stage (4 months-old) was significantly increased. Levels of superoxide $\left(\mathrm{O}_{2}{ }^{-}\right)$and hydrogen peroxide $\left(\mathrm{H}_{2} \mathrm{O}_{2}\right)$ the major forms of reactive oxygen species (ROS) were significantly increased and accumulated after 3 and 5 days from symptom appearance in infected soybean plants. Electrolyte leakage (EL) values which indicate to the membrane permeability were increased after 3 days from symptom appearance, while the activity of antioxidant enzymes such as catalase (CAT), peroxidase (POX) and polyphenol oxidase (PPO) as well as chlorophyll $A / B$ concentrations were significantly decreased. Antioxidant enzyme activities in infected plants were not enough for ROSscavenging and initiated the programmed cell death and led for sudden death of susceptible soybean plants. Therefore, a detailed understanding of the biochemical processes responsible for this interaction remains unclear. It could be recommended to plant breeders for creation a new soybean cultivars over-accumulating antioxidant enzyme activities as well as overexpressing antioxidant genes as well. This could decrease the environmental pollutions as a result of using fungicides which are harmful for human health and causes to much hard currency. Giving more attention to antioxidant enzymes activity and ROS levels are needed and might be useful for discovering a new alternative disease control strategies.

\section{Acknowledgements}

I want to express my thanks to Dr. Akram Rashad Morsy for giving me the opportunity for working with soybean plants in the farm of Sakha Agricultural Research Station. The laboratory investigation was conducted in Plant Pathology and Biotechnology Lab. under accreditation of ISO 17025 and EPCRS Excellence Centre, Dept. of Agric. Botany, Fac. of Agric., Kafrelsheikh University, Egypt. 


\section{REFERENCES}

Abbas, S.M., (2012). Effects of low temperature and selenium application on growth and the physiological changes in sorghum seedlings. J. Stress Physiol. Biochem., 8: 268-286.

Abdelaal, Kh.A.A.; Y.M. Hafez; Samar M. Adel; W.A. Youseef; and M.M. Badr (2014). Biochemical, histological and molecular changes in some Egyptian wheat varieties infected with stripe rust (Puccinia striiformis $\mathrm{f}$. sp. tritici). Egypt. J. Biol. Pest Cont., 24(2): 421-429.

Abdel-Monaim M.F.; M.E. Ismail; and K.M. Morsy (2011). Induction of systematic resistance in soybean plants against Fusarium wilt disease by seed treatment with benzothiadiazole and humic acid. Not. Sci. Biol., 3(2): 80-89.

Ádám, A.; T. Farkas; G. Somlyai; M. Hevesi; and Z. Király (1989). Consequence of $\mathrm{O}_{2}{ }^{-}$generation during a bacterially induced hypersensitive reaction in tobacco: deterioration of membrane lipids. Physiol. Molec. Plant Pathol., 34: 13-26.

Adam, A.L.; A.A. Gala; K. Manninger and B. Barna (2000). Inhibition of the development of leaf rust (Puccinia recondita) by treatment of wheat with allopurinol and production of a hypersensitive- like reaction in a compatible host. Plant Pathol., 49: 317-323.

Aebi, H. (1984). Catalase in vitro. Methods Enzymol., 105: 121-126.

Almagro, L., L.V. Gómez Ros; S. Belchi-Navarro; R. Bru; A. Ros Barceló; and M.A., Pedreno (2009). Class III peroxidases in plant defense reactions. J. Experimental Botany 60: 377-390.

Aoki, T.; K. O'Donnell; Y. Homma; AR. Lattanzi (2003). Sudden death syndrome of soybean is caused by two morphologically and phylogenetically distinct species within the Fusarium solani species complex - F. virguliforme in North America and F. tucumaniae in South America. Mycologia 95: 660-684.

Apel, K.; and H. Hirt (2004). Reactive oxygen species: metabolism, oxidative stress and signal transduction. Annu Rev. Plant Biol. 55: 373-399.

Asada, K.; and M. Takahashi (1987). Production and scavenging of active oxygen in photosynthesis. In DJ Kyle, CB Osmond, CJ Amtzen, eds, Photoinhibition, Elsevier, Amsterdam, 9: 227-287.

Atia, M.M.M.; Buchenauer, H.; Aly, A.Z.; and Abou-Zaid, M.I. (2005). Chitosan induced cell death, SA, pathogenesis related-protein and active enhancement of resistance in tomato to Phytophthora infestans the late blight pathogen. J. Bio. Agric., Horticulture, 23: 175-197.

Blokhina, O.; and K.V. Fagerstedt (2010). "Reactive oxygen species and nitric oxide in plant mitochondria: origin and redundant regulatory systems," Physiol. Plantarum, 138(4): 447-462.

Corpas, F. J.; J. M. Palma; L. M. Sandalio; R. Valderrama; J. B. Barroso; and L. A. del Río (2008). "Peroxisomal xanthine oxidoreductase: characterization of the enzyme from pea (Pisum sativum L.) leaves". J. of Plant Physiol., 165(13): 1319-1330. 
Coseteng, M.Y.; and C.Y. Lee (1978). Changes in apple poly- phenol oxidase and polyphenol concentrations in relation to degree of browning. $J$ Food Sci. 52: 985-989.

Del Río, L. A.; L. M. Sandalio; F. J. Corpas; J. M. Palma; and J. B. Barroso (2006). "Reactive oxygen species and reactive nitrogen species in peroxisomes. Production, scavenging, and role in cell signaling". Plant Physiol., 141(2): 330-335.

Díaz Arias, M.M.; L.F. Leandro; and G.P. Munkvold (2013). Aggressiveness of Fusarium species and impact of root infection on growth and yield of soybeans. Phytopathol. 103: 822-832.

Djebali, N.; H. Mhadhbi; C. Jacquet; T. Huguet; and M.E. Aouani (2007). Involvement of hydrogen peroxide, peroxidase and superoxide dismutase in response of Medicago truncatula lines differing in susceptibility to Phoma medicaginis infection. J. Phytopathol., 155: 633-640.

El- Khallal, S.M. (2007). Induction and modulation of resistance in tomato plants against Fusarium wilt disease by bioagent fungi (Arbuscular mycorrhiza) and/or hormonal elicitors (jasmonic acid and salicylic acid): 2-changes in the antioxidant enzymes, phenolic compounds and pathogen related- proteins. Aust. J. Basic Appl. Sci. 1(4): 717-732.

El-Zahaby, H. M.; G. Gullner and Z. Király (1995). Effects of powdery mildew infection of barley on the ascorbate-glutathione cycle and other antioxidants in different host-pathogen interactions. Phytopathol., 85: 1225-1230.

Foyer, C.H.; and Noctor G. (2005). Redox homeostasis and antioxidant signaling: a metabolic interface between stress perception and physiological responses. Plant Cell 17: 1866-1875.

Garraway, M.O.; M. Akhtar and E.C.W. Wokoma (1989). Effect of high temperature stress on peroxidase activity and electrolyte leakage in relation to sporulation of Bipolaris maydis race T. Phytopathol, 79: 800805.

Gechev, T.; I. Gadjev; F.VanBreusegem; D. Inzé; S. Dukiandjiev; V. Toneva and I. Minkov (2002). Hydrogen peroxide protects tobacco from oxidative stress by inducing a set of antioxidant enzymes. Cell Mol. Life Sci. 59:708-714.

Goicoechea, N.; J.S. Aguirreolea; and J.M. Garcia-Mina (2001). Gas exchange and flowering in Verticillium-wilted pepper plants. J. Phytopathol., 149: 281-286.

Goodman, R.N.; Z. Kiraly and K.R. Wood (1986). The Biochemistry and Physiology of Plant Disease. University of Missouri Press, Columbia, MO, 433.

Grau, C.R.; V.L., Radke; and F.L. Gillespie (1982). Resistance of soybean cultivars to Sclerotinia sclerotiorum. Plant Dis., 66: 506-508.

Hafez, Y.M. (2015). A pivotal role of reactive oxygen species in non-host resistance mechanisms in legume and cereal plants to the incompatible pathogens. Int. J. Phytopathol., 04 (01): 43-53. 
Hafez, Y.M. and N. A. El-Baghdady (2013). Role of reactive oxygen species in suppression of barley powdery mildew fungus, Blumeria graminis f.sp. hordei with benzothiadiazole and riboflavin. Egyp. J. Biol. Pest Cont., 23(1): 125-132.

Hafez, Y.M.; R. Bacso; Z. Király; A. Kunstler and L. Király (2012). Upregulation of antioxidants in tobacco by low concentrations of $\mathrm{H}_{2} \mathrm{O}_{2}$ suppresses necrotic disease symptoms. Phytopathol., 102: 848-856.

Hafez, Y.M.; R.Y. Mourad; M. Mansour and Kh. A.A. Abdelaal (2014). Impact of non-traditional compounds and fungicides on physiological and biochemical characters of barely infected with Blumeria graminis $\mathrm{f}$. $\mathrm{sp}$. hordei under field condtition. Egy. J. Biol. Pest Cont. 24(2): 445-453.

Hagborg, W.A.F. (1970). A device for injecting solutions and suspensions into thin leaves of plants. Can. J. Bot., 48: 1135-1136.

Halliwell, B. and J. M. C. Gutteridge (1999). Free Radicals in Biology and Medicine: Oxford University Press.

Hammerschmidt, R.; E.M. Nuckles and J. Kuć (1982). Association of enhanced peroxidase activity with induced systemic resistance of cucumber to Colletotrichum lagenarium. Physiol. Plant Pathol, 20(1): 73-82.

Harrach, B. D., J. Fodor; M. Pogány; J. Preuss and B. Barna (2008). Antioxidant, ethylene and membrane leakage responses to powdery mildew infection of near-isogenic barley lines with various types of resistance. Eur. J. Plant Pathol., 121: 21-33.

Hartman, G.L.; G.R. Noel; and L.E. Gray (1995). Occurrence of soybean sudden death syndrome in east-central Illinois and associated yield losses. Plant Dis. 79: 314-318.

Harwood, J.L. (1997). Plant lipid metabolism. In: Dey P.M., Harborne J.B. (eds) Plant Biochemistry. Academic Press, San Diego, 237-271.

Heath, M. (2000). Hypersensitive response related death. Plant Mole Biol.44: 321-334.

Heyno, E.; V. Mary; P. Schopfer; and A. Krieger-Liszkay (2011). "Oxygen activation at the plasma membrane: relation between superoxide and hydroxyl radical production by isolated membranes," Planta, 234(1): 35-45.

Hirrel, M.C. (1983). Sudden death syndrome of soybean - a disease of unknown etiology. Phytopathol. 77 (Suppl.), 1689.

Houimli, S.M.; M. Denden and B.D. Mouhandes (2010). Effects of 24epibrassinolide on growth, chlorophyll, electrolyte leakage and proline by pepper plants under NaCl-stress. Eur. Asia. J. Bio. Sci., 4: 96-104.

Hückelhoven, R.; J. Fodor; C. Preis; and K-H. Kogel (1999). Hypersensitive cell death and papilla formation in barley attacked by the powdery mildew fungus are associated with $\mathrm{H}_{2} \mathrm{O}_{2}$ but not with salicylic acid accumulation. Plant Physiol., 119: 1251-1260.

Jin, H.; G. L. Hartman; C. D. Nickell; and J. M. Widholm (1996). Phytotoxicity of culture filtrates from Fusarium solani, the causal agent of sudden death syndrome of soybean. Plant Dis. 80: 922-927. 
Király, L.; A. Künstler; R. Bacsó; Y. M. Hafez and Z. Király (2013). Similarities and Differences in Plant and Animal Immune Systems -What is Inhibiting Pathogens? Acta Phytopathol. Entomol. Hung., 45 (1): 13-29.

Lamb, C.; and R.A. Dixon (1997). The oxidative burst in plant disease resistance. Annu Rev Plant Physiol. Plant Mol. Biol., 48: 251-275.

Lebeda, A.; L. Luhová; M. Sedlárová; and D. Jancová (2001). The role of enzymes in plant-fungal pathogens interactions. J. Plant Dis. Protec. 108: 89-111.

Leshem, Y. (1987). Membrane phospholipid catabolism and $\mathrm{Ca}^{2+}$ activity in control of senescence. Physiol Plant 69: 551-559.

Leslie, J.F.; and B.A. Summerell (2006). The Fusarium Laboratory Manual. Blackwell Publishing, Oxford, UK, 388.

Levine, A.; R. Tenhaken; R. Dixon and C. Lamb (1994). $\mathrm{H}_{2} \mathrm{O}_{2}$ from the oxidative burst orchestrates the plant hypersensitive disease resistance response. Cell 79: 583-593.

Li, S.; G. L. Hartman; B. S. Lee; and J. W. Widholm (2000). Identification of a stressinduced protein in stem exudates of soybean seedlings rootinfected with Fusarium solani f. sp. glycines. Plant Physiol. and Biochem. 38: 803-809.

Lindenthal, M.; U. Steiner; H.W. Dehne and E.C. Oerke (2005). Effect of downy mildew development on transpiration of cucumber leaves visualized by digital infrared thermography. Phytopathol. 95: 233-240.

Lozovaya, V.V.; A.V. Lygin; O.V. Zernova; S. Li; G.L. Hartman; and J.M. Widholm (2006). Lignin degradation by Fusarium solani f. sp. glycines. Plant Dis. 90: 77-82.

Lozovaya, V.V.; A.V. Lygin; S. Li; G.L. Hartman; and J.M. Widholm (2004). Biochemical responses of soybean to Fusarium solani f. sp. glycines infection. Crop Sci. 44: 819-826.

Martinez, C.; J.C. Baccou; E. Bresson; Y. Bessac; J.F. Daniel; A. Jalloul; J.L. Montillet; J.P. Geiger; K. Assigbetse and M. Nicole (2000). Salicylic acid mediated by the oxidative burst is a key molecule in local and systemic response of cotton challenged by a virulent race of Xanthomonas campestris pv. malvacearum. Plant Physiol., 122: 757766.

Mittler, R.; S. Vanderauwera; M. Gollery; and F. Van Breusegem (2004). Reactive oxygen gene network of plants. Trends Plant Sci. 9: 490-498.

Moran, R.; and D. Porath (1982). Chlorophyll determination in intact tissues using N,N-Dimethyl formamide. Plant Physiol., 69: 1370-1381.

Moriondo, M.; S. Orlandini; A. Giuntoli and M. Bindi (2005). The effect of downy and powdery mildew on grapevine (Vitis vinifera L.) leaf gas exchange. J. Phytopathol., 153: 350-357.

Mueller, D.S.; G.L. Hartman; R.L. Nelson; and W.L. Pedersen (2002). Evaluation of Glycine max germ plasma for resistance to Fusarium solani f. sp. glycines. Plant Dis. 86: 741-746.

Noctor, G.; and C. H. Foyer (1998). "Ascorbate and glutathione: keeping active oxygen under control," Annual Rev. of Plant Biol., 49: 249-279.

O'Mahony, M. (1986). Sensory Evaluation of Food: Statistical Methods and Procedures. CRC Press, p. 487. 
Passardi, F.; C. Penel; and C. Dunand (2004). Performing the paradoxical: how plant peroxidases modify the cell wall. Trends in Plant Sci. 9: 534540.

Pearce, R.S. (2001). Plant freezing and damage. Ann. Bot., 87: 417-424.

Polkowska-Kowalczyk, L.; and U. Maciejewska (2001). The oxidative processes induced in cell suspensions of Solanum species by culture filtrate of Phytophthora infestans. Zeitschrift für Naturforschung, 56: 235-244.

Ray, H.; D.S. Douches and R. Hammerschmidt (1998). Transformation of potato with cucumber peroxidase: expression and disease response. Physiol. Mol. Plant Pathol., 53: 93-103.

Robert, C.; M.O. Bancal; P. Nicolas; C. Lannou; and B. Ney (2004). Analysis and modelling of effects of leaf rust and Septoria tritici blotch on wheat growth. J. Experi. Botany, 55: 1079-1094.

Roy, K.W., (1997a). Fusarium solani on soybean roots: nomenclature of the causal agent of sudden death syndrome and identity and relevance of F. solani form B. Plant Dis. 81, 259-266.

Roy, K.W., (1997b). Sporulation of Fusarium solani glycines, causal agent of sudden death syndrome, on soybeans in the Midwestern and Southern United States. Plant Dis. 81: 566-569.

Roy, K.W.; G.W. Lawrence; H.H. Hodges; K.S. McLean; and J.F. Killebrew (1989). Sudden death syndrome of soybean: Fusarium solani as incitant and relation of Heterodera glycines to disease severity. Phytopathol. 79: 191-197.

Rupe, J.C., (1989). Frequency and pathogenicity of Fusarium solani recovered from soybeans with sudden death syndrome. Plant Dis. 73: 581-584.

Rupe, J.C.; and G.L. Hartman (1999). Sudden death syndrome. In: Hartman G. L., Sinclair J. B., Rupe J.C. (eds). Compendium of Soybean Diseases, APS Press, St. Paul, MN, USA, 37-39.

Sanogo, S.; and X.B. Yang (2001). Relation of sand content, $\mathrm{pH}$, and potassium and phosphorus nutrition to the development of sudden death syndrome in soybean. Can. J. Plant Pathol. 23: 174-180.

Scandalios, G.; L. Guan; and A. N. Polidoros (1997). "Catalases in plants: gene structure, properties, regulation and expression," in Oxidative Stress and the Molecular Biology of Antioxidants Defenses. Cold Spring Harbor Laboratory Press, New York, NY, USA, 343-406.

Scherm, H.; and X.B. Yang (1996). Development of sudden death syndrome of soybean in relation to soil temperature and soil water matric potential. Phytopathol. 86: 642-649.

Scherm, H.; and X.B. Yang (1998). Soil variables associated with sudden death syndrome in soybean fields in lowa. Plant Dis. 82: 1152-1157.

Scherm, H.; and X.B. Yang (1999). Risk assessment for sudden death syndrome of soybean in the north-central United States. Agric. Syst. 59: 301-310. 
Scholes, J.D.; P.J. Lee; P. Horton; and D.H. Lewis (1994). Invertase: understanding changes in the photosynthetic and carbohydrate metabolism of barley leaves infected with powdery mildew. New Phytologist, 126: 213-222.

Sharma, P.; A.B. Jha; R.S. Dubey; M. Pessarakli (2012). Reactive oxygen species, oxidative damage, and antioxidative defense mechanism in plants under stressful conditions J. Bot., 1-26.

Simon, E.W. (1974). Phospholipids and plant membrane permeability. New Phytol 73: 377-420.

Sriram, S.; T. Raguchander; S. Babu; R. Nandakumar;V. Shanmugam and P. Vidhyasekaran (2000). Inactivation of phytotoxin produced by the rice sheath blight pathogen Rhizoctonia solani. Can. J. Microbiol., 46: 520524.

Szalai, G.; T. Janda; E. Páldi; and Z. Szigeti (1996). Role of light in the development of post-chilling symptoms in maize. J Plant Physiol 148: 378-383.

Torres, M.A.; J.D.G. Jones; and J.L. Dangl (2006). Reactive oxygen species signalling response to pathogens. Plant Physiol. 141: 373-378.

Van Breusegem, F.; and J.F. Dat (2006). Reactive oxygen species in plant cell death. Plant Physiol., 141: 384-390.

Vidhyasekaran, P.; A. Ramanathan; A.L. Rathinakumar; and R. Samiyappan (2002). Induction of defense-mechanisms in mungbean suspension cultured cells by elicitor from Macrophomina phaseolina. Acta Phytopathol. Entomol. Hungarica, 37: 91-98.

Wilcox, J.R. (2004). World Distribution and Trade of Soybean. In H.R. Boerma and J.E. Specht (ed.) Soybeans: Improvement, Production and Uses. ( ${ }^{\text {rd }}$ ed.). Agron. Monogr. 16. ASA, CSSA, and SSSA, Madison, WI, 1-14.

Wright, M.; and Simon E.W. (1973). Chilling injury in cucumber leaves. J Exp. Bot 24: 400-411.

Xin, M.; X. Wang; H. Peng; Y. Yao; C. Xie; Y. Han; Z. Ni and Q. Sun (2012). Transcriptome comparison of susceptible and resistant wheat in response to powdery mildew infection. Genomics Proteomics Bioinformatics, 10: 94-106.

Zhou, B.; Z. Guoand Z. Liu (2005). Effects of abscisic acid on antioxidant systems of Stylosanthes guianensis under chilling stress. Crop Sci., 45: 599-605. 


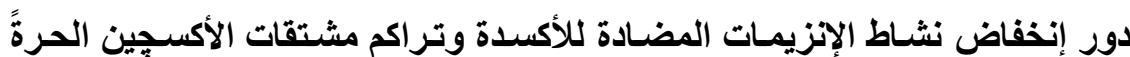

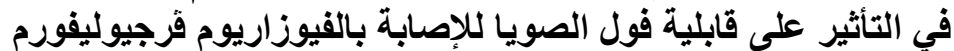

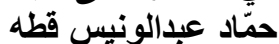

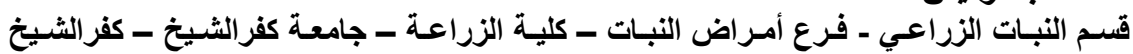

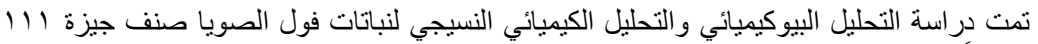

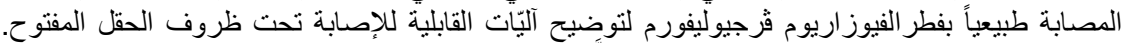

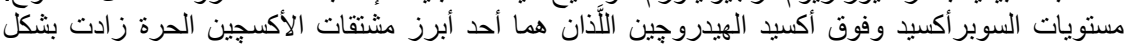

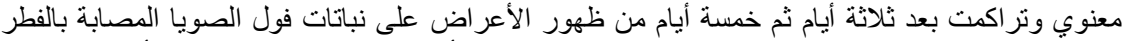

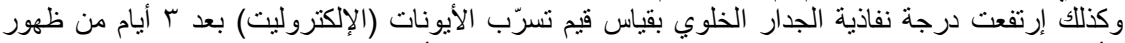

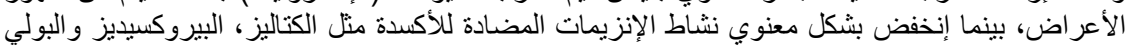

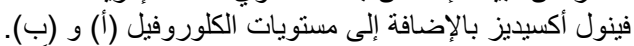

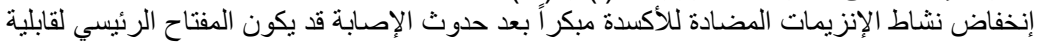

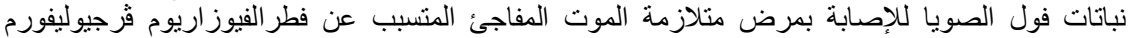

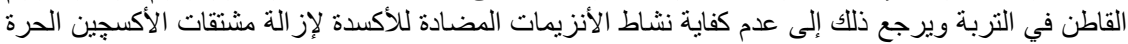

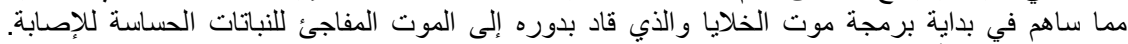

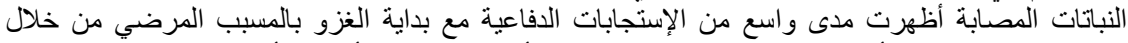

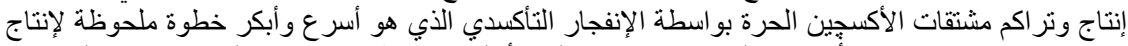

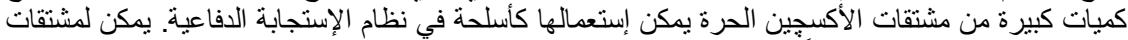

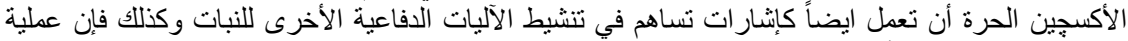

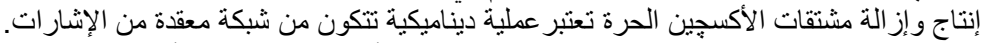

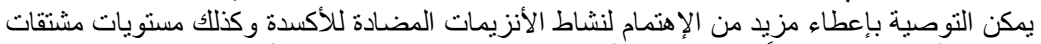

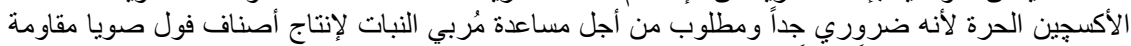

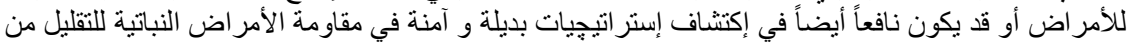

